Unedited version submitted to Studies in Higher Education, 2013

DOI : 10.1080/03075079.2013.777149

\title{
Research universities, technology transfer, and job creation: What infrastructure, for what training?
}

\author{
Christian Brodhag \\ Professor \\ Henri Fayol Institute \\ National School of Mines - Saint-Etienne \\ surface mail: 158, Cours Fauriel \\ 42023 Saint-Etienne Cedex 02, France \\ Mel : brodhag@emse.fr \\ Tel: +33477420017 \\ http://brodhag.org
}

\section{Summary}

Technology transfer and innovation are considered as major contributions to support development. They place knowledge and its dissemination in society at the heart of the development process.

This article will consider the role of Research Universities and how they can interact with the key actors and institutions involved in innovation ecosystems. Considering different approaches of innovation and Institutional Analysis Design, it proposes an institutional model of innovation where different authorities produce rules and knowledge that are mobilized and/or changed in Action Arenas.

On this conceptual basis, an initiative is described: Integrated Pole of Excellence for renewable energy in West Africa conceived as a resource and knowledge centre connected to project implementation.

Keywords

Research Universities, innovation, innovation ecosystems, knowledge, Institutional Analysis Design,

\section{Innovation}

\section{Technology}

Technology is an essential component of development. But the ideology of technological determinism which holds that technological change is an autonomous factor independent of society that brings progress is no longer valid. The slogan of Chicago's World Fair in 1933, "A Century of Progress" appears to be obsolete: "Science discovers, genius invents, industry applies, and man adapts himself to, or is molded by new things". The collective control of risk and opportunities of technologies had put those visions in public debate. Research universities cannot consider themselves as a place of production and a reservoir of knowledge to be spread, but as a stakeholder in the broader process of production and use of knowledge that we will explore in this article. 
Transfer of technologies has been on the international agenda for a long time. The lack of the scientific and technological capacities of developing countries was considered as an illustration of the inequitable world order (Sagasti 1979, 15).

The developing world is characterized by an exogenous scientific and technological base dependent on technological transfer from the North, while industrialized countries have an endogenous scientific and technological base, characterized by strong interactions between scientific activities, technological capacities associated with modern production, and traditional technological capabilities (Sagasti 1979, 16-17). The question is not the mere transfer of technologies through market forces regardless of their quality but a more complex process of appropriation of the technology by society, with interventions of the state and various stakeholders.

The question for Research universities in developing countries is not therefore one of simple affiliation to a northern model of University, but the need to be rooted in issues of knowledge and development of their own countries. The transfer, i.e. the appropriation of technology by the market or by society, has to be discussed in the conceptual field of innovation which appears to be more relevant than that of mere technology.

\section{Scope of the innovation}

The definition and the scope of innovation have evolved since the seminal work of Schumpeter in 1934. Schumpeter divides the technological change process into three stages (1) the invention process with the generation of new ideas or scientific knowledge, (2) the innovation process with the development of new ideas into marketable products and processes, (3) the diffusion stage, in which the new products and processes are diffused across the market (Schumpeter 1939). The first stage, the invention stage, is dominated by scientific activities, where universities have a natural leadership. The innovation stage relies on three separate roles: the capitalist, who invests, the inventor, who generates the idea and the entrepreneur, who adapts the idea to the market. This trilogy of stakeholders developed by Schumpeter as part of an analysis of capitalism is also found in the context of public policies of research and innovation with the public funder of research, the universities and the entrepreneur.

Since then different theories and approaches have been developed, based on various postures and different scientific backgrounds (economics, management, sociology, engineering...) but also on different types of innovation.

To enable a convergence of approach and a better understanding of innovative processes based on a reliable statistical system, the Organization of Economic Cooperation and Development (OECD) and Eurostat have published the Oslo Manual (OECD, EUROSTAT 2005), which includes both definitions of concepts and classifications, and a set of guidelines for the measurement of innovation in the international arena. This is an essential basis for approaching innovation.

\section{Types of innovations}

Schumpeter proposed a list of five types of innovations: i) Introduction of new products, ii) Introduction of new methods of production, iii) Opening of new markets, iv) Development of new sources of supply for raw materials or other inputs, v) Creation of new market structures in an industry (Schumpeter 1934).

While the definition of innovation in the second edition of the Oslo manual was limited to technology and process, the last version defines an innovation as "the implementation of a new or significantly improved product (good or service), or process, a new marketing method, or a new organizational method in business practices, workplace organisation or external relations." (OECD, EUROSTAT 2005, §146). 
As with Schumpeter the innovation considered by the Oslo Manual is centered on the firm, but innovation must contain a degree of novelty either for the firm, for the market or for the world. A product, process, marketing method or organizational method may already have been implemented by other firms, but if it is new to the firm then it is an innovation for that particular firm (OECD, EUROSTAT 2005). The same reasoning can be applied at the national level, a technology mastered in one country may be considered as an innovation in another.

\section{Incremental or radical innovation}

Several expressions have been used to describe the novelty of innovation compared to progressive and incremental change: radical, breakthrough, highly novel, disruptive, discontinuous, significant, major... The different terms belong to different bodies of literature, and rely on different theoretical perspectives and different measures of the novelty of innovation (Chandy and Prabhu 2011; Amara, Landry and Halilem 2012). They depend also on the actor for whom it is a novelty, the firm or the market, or if it affects knowledge (scientific breakthrough) or social rules and practices...

Development is generally considered as a continuous process, accepting only incremental changes, and being unable to manage fractures associated with radical innovation because of the phenomenon of creative destruction, a concept proposed by Schumpeter, associated with the negative effects of market capitalism. In this perspective, developing countries should go through the same stages of development as the northern countries. In the context of information and communication technologies, with the innovative use of cell phones in countries with few wired connections for example, disruptive innovations are qualified as leapfrogging. In the context of sustainable development the same concept refers to the leapfrogging from traditional, polluting and resource-intensive production patterns to more advanced ones in terms of eco-efficiency for the use of natural resources.

\section{The driving forces of innovation}

Two forces were considered in innovation and technical change: the so-called technologypush perspective, which pinpointed the key role that science and technology play in developing technological innovations, and a demand-pull. During the sixties and seventies, public policies adopted the technology push model that justified public investment in research and development. In parallel "scholars embracing a demand-pull approach identified a broader set of market features, including characteristics of the end market (particularly the users) and the economy as a whole that affects the performance of innovation. The juxtaposition of these two approaches to innovation fostered a fruitful debate that reached its apex in the Seventies." (Di Stefanoa, Gambardella and Verona 2012, 1283)

The push vision is closely connected to a diffusion model of innovation.

\section{Diffusion model}

The classic text in this field of diffusion of innovations is that of Everett Rogers. He proposed a classification of innovation adopters into five categories: "innovators", "early adopters", "early majority", "late majority" and "laggards" (Rogers 1962). Rogers defines also five intrinsic characteristics of innovations that influence an individual's decision to adopt or reject an innovation: the relative advantage over the previous generation, the level of compatibility with an individual's way of life, the perception of complexity or simplicity to use, the ability to test an innovation, and the observability of others in personal networks. For disruptive innovation, with high technology content, we should consider Geoffrey Moore's variation of this diffusion model that describes a chasm between the early adopters and early majority (Moore 1991). Many disruptive technology innovations do not successfully cross the chasm and simply disappear. This chasm is a transition between two worlds 
characterized by their different relationship to technology (Norman 1998). Discontinuity of the innovation process is linked to the difference in expectations of types of consumers who buy the new product or use the new technology. This chalm is the transition between sensitive consumers, enthusiasts of innovation and technology, and other more rational consumers, waiting for evidence of performance and for standard technology to be chosen.

This analysis shows that there is a limit to the technological complexity. One solution is to increase the desire of the population for technology and innovation, an issue where the education system can play a role. Another is to involve downstream users in the design of products, especially those less committed to innovation. The general level of culture in technology, such as energy for example, is important to enable broad access to energy and promote energy efficiency. We must add to this the question of generations, generation Y, born in the mid-1980's and later, grew up with technology and is tech-savvy. This is of some importance when one considers the education and initial training system and the role of these young people in the introduction of novelty into society and firms. In this context it is necessary to examine the role of the Internet and how knowledge is disseminated by the research universities by distance learning, but more generally on the quality and traceability of knowledge available on the Internet.

The diffusion model responds to two main questions: What qualities make innovations spread and what characteristics of adopters explain the rhythm of this adoption? One reason of the success of this approach is that it lends itself to classification, segmentation and statistical analysis. Diffusionist analyses are static and do not take into account the construction of social relations.

\section{The growing complexity of push/pull debate}

The two basic models of technology push and market pull conceived as a black box (Lundvall 1985,28 ) have since become more complex both because of the actors themselves and the variety of arrangements and initiatives they have implemented and the institutions that have placed innovation to serve public goals. Public intervention is no longer limited to the maximizing the benefits of science independently of the question of objectives and the nature of the applications, but seeks social or environmental outcomes through technology and innovation policies.

Environmental regulations, for example, are thus seen also as a driving force for innovation (Porter 1991; Porter and van der Linde 1995). In the context of sustainability issues, a regulation push mechanism has been highlighted (Hansen, Grosse-Dunker and Reichwald 2009).

Actors involved in innovation have diversified far beyond the Schumpeter trilogy (capitalist, inventor, and entrepreneur) and public actors. An open innovation paradigm is opposed to the previous model of closed innovation: "Open innovation means that valuable ideas can come from inside or outside the company and can go to market from inside or outside the company as well. This approach places external ideas and external path to market at the same level of importance as that reserved for internal ideas and paths to market during Closed Innovation era." (Chesbrough 2003, 43). The degree of openness to different stakeholders can go in circles growing from inside the company to the outside: $\mathrm{R} \& \mathrm{D}$, employees, customers, the innovation community and the general public.

\begin{tabular}{|l|l|l|}
\hline & \multicolumn{1}{|c|}{ Classical approach } & \multicolumn{1}{c|}{ New economy and sustainability } \\
\hline Innovation pull & $\bullet$ Market pull & $\begin{array}{l}\text { - Society and vision pull (Vollenbroek 2002) } \\
\text { - Open innovation (Chesbrough 2003) } \\
\text { - Collaborative pull (Weaver 2008) }\end{array}$ \\
\hline
\end{tabular}




\begin{tabular}{|l|l|l|}
\hline & & $\begin{array}{l}\text { - Sustainability oriented innovations } \\
\text { (Hansen, Grosse-Dunker and Reichwald } \\
\text { 2009) }\end{array}$ \\
\hline Innovation push & $\bullet$ Technology push & $\begin{array}{l}\text { - Regulation push (M. Porter 1991) (Porter } \\
\text { and van der Linde 1995) } \\
\text { Regulation-induced innovation for } \\
\text { sustainable development (Ashford and Hall } \\
\text { 2011) }\end{array}$ \\
\hline
\end{tabular}

Table 1 : renewal of the push and pull debate.

The emergence in business and in the market place of concepts such as social responsibility and the creation of shared value (Porter and Kramer 2011), supports these various forms of cooperative innovation. In a broader view, expectations of society polarize the space available for innovation and change.

In the vision pull conception, the fact that the actors share the same vision of the future leads them to cooperate in the change. Different approaches may support this approach, such as backcasting which defines a desirable future as a background for the opinion forming of the general public concerned, and for the decisions of policy makers (Dreborg 1996); and also to help identify policies and programs to reach the goal.

Challenges of sustainability offer significant potential for innovations and related business opportunities in both push and pull perspective; a regulatory push due to new regulations and laws in social and environmental matters that increase the pressure for innovation and a vision pull as a new source of ideas and visions leading to new business opportunities : reduction of costs through increases in efficiency, reduction of risks, planning reliability, assurance of legitimacy, attraction of new customers and development of new product and business segments. (Hansen, Grosse-Dunker and Reichwald 2009, 684)

Firms that integrate principles of sustainable development and a new philosophy of responsibility as a paradigm are able to generate breaking innovations (Asselineau and PiréLechalard 2009). Social responsibility, conceived as the contribution of the organization to sustainable development (ISO 26000:2010(E) 2010), can be a driving force for innovation in two ways, on the procedural side in organizing stakeholder's engagements and on the substantive practical side on subjects considered by SR. Social responsibility involves engagement with stakeholders that may facilitate the formation of an innovation network or a business ecosystem, and confidence in cooperative processes. Ethical SR could help to avoid abuses of power which are considered by Moore as a risk in business ecosystems (see infra) in relation to antitrust and competition issues (Moore 2005, 49).

SR innovation addresses various domains: social improvements (i.e. health, education, community development...) such as for example "base of the pyramid" approaches addressing the poorest, or environmental innovation, eco-innovation, ecodesign of products, or clean-technology (Hockerts \& Morsing, 2008, p. 14) (Brodhag et al. 2011).

\section{Systems of innovation}

The opening of the innovation process to various actors should be also considered in terms of the relationships that are built between these actors. Designing a network of actors, the nature of their relationship (cooperative/competitive), and the link with institutions... has led to the introduction of the concept of innovation systems (Lundvall 1985; Freeman 1987).

At the end of the 1980s and during the 1990s, theories of system and networks of innovation were developed by scholars from various disciplines, sociology, management... under the label "systems of innovation" assuming that innovative firms are linked to a highly diversified set of agents through networks of collaboration and exchange of information. 
Those sources of information are external to the firm: clients, suppliers, consultants, government agencies, government laboratories, university research, etc... (Landry, Amara and Lamari 2000,5). The systems approach goes beyond the mere consideration of a variety of actors but focuses on their interactions in a comprehensive, holistic and systemic logic (Mercier-Laurent 2011). Focusing on how those system works, Actor-network Theory (ANT) describes processes in which actors build networks and interact through a "translation" process. According to Callon (1986), this process can be divided into four stages: (1) Problematization, definition of the problem by the actors in the network and their individual goals of a common objective, an obligatory passage point (OPP) through which all actors in the network must pass in order to reach their individual goals, (2) Interessement stabilization of the actor's identity and connection to the network that has been formed in the first stage, (3) Enrolment locking the actors into place and defining their roles and identities in the network that fulfill certain objectives inscribed in the OPP and (4) Mobilization of the network represented by the main actor, which in this way becomes a macro actor (Callon 1986; Akrich, Callon and Latour 1988).

Innovation systems have been proposed at different levels national, regional (Edquist 2011, 181) or local but also technological innovation systems and sectorial innovation systems. Systems of innovation can be defined as the "the determinants of innovation processes - all important economic, social, political, organizational, institutional, and other factors that influence the development, diffusion and use of innovations" (Edquist 2011, 182)

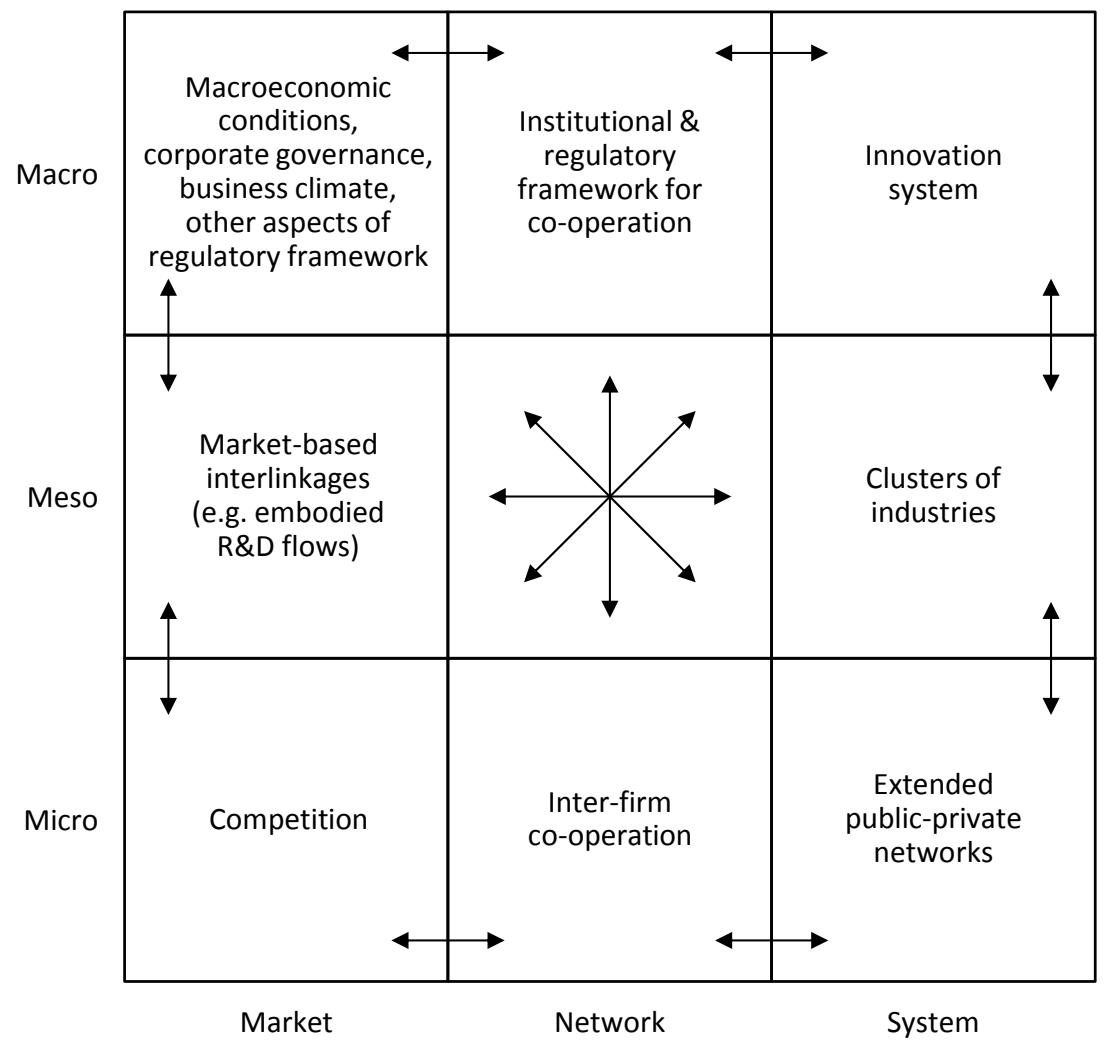

Figure 1 : Interactions in innovation systems (OECD 2007)

The distinction between networks and systems is made by some authors. The OECD proposes a double distinction: that of the levels of the micro, meso and macro approach on the one hand, and levels of integration on the other hand: the single market, networks or closer 
integration into a system (See Figure 1) (OECD 2007). This integrated vision and macro system is also called an ecosystem by some authors.

The empty cell in the center of Figure 1 can be filled by the Research Universities that can develop interactions with each type of system, by providing them with the relevant knowledge.

\section{National innovation system}

The domination of the technology push approach and the link between research and innovation has led countries to consider their research policies in terms of R \& D for the commercialization, even more exceptional the social application, of the fruits of research and thus to develop national innovation policies. The expression "national system of innovation" was, in published form, first used by Freemann in a study on Japan (Edquist 2011), which defines it as a "network of institutions in the public and private sector whose activities and indications initiate, import and diffuse new technologies" (Freeman 1987).

Considering the general institutional environment which determines the broad parameters within which firms operate (OECD, EUROSTAT 2005, §105), public policies can address directly most of them:

- The basic educational system for the general population, which determines minimum educational standards in the workforce and the domestic consumer market.

- The university system.

- The specialized technical training system.

- The science and research base.

- Innovation policies and other government policies that influence innovation by firms.

- Legislative and macroeconomic settings such as patent law, taxation, corporate governance rules and policies relating to interest and exchange rates, tariffs, and competition.

- The communications infrastructure, including roads and telecommunication networks.

And a few others on which public influence is more indirect:

- Common pools of codified knowledge, such as publications, technical, environmental and management standards.

- Financial institutions which determine, for example, the ease of access to venture capital.

- Market accessibility, including possibilities for the establishment of close relations with customers as well as matters such as size and ease of access.

- Industry structure and the competitive environment, including the existence of supplier firms in complementary sectors.

Rules and knowledge conveyed by all these actors are key elements of innovation alongside the economy and market forces. Universities, with both training and research activities, can play a role of capacity building vis-à-vis each of these actors

These issues are not considered separately, but as part of a national innovation system, which can be evaluated through surveys conducted on the basis of the Oslo Manual.

The involvement of the University in innovation ecosystems or Action Arena is often a local one; "many of these initiatives seek to spur local economic development based on university research e.g., by creating "science parks" located nearby research university campuses, support for "business incubators" and public "seed capital" funds, and the organization of other forms of "bridging institutions" that are believed to link universities to industrial innovation." (Mowery and Sampat 2011, 209). 


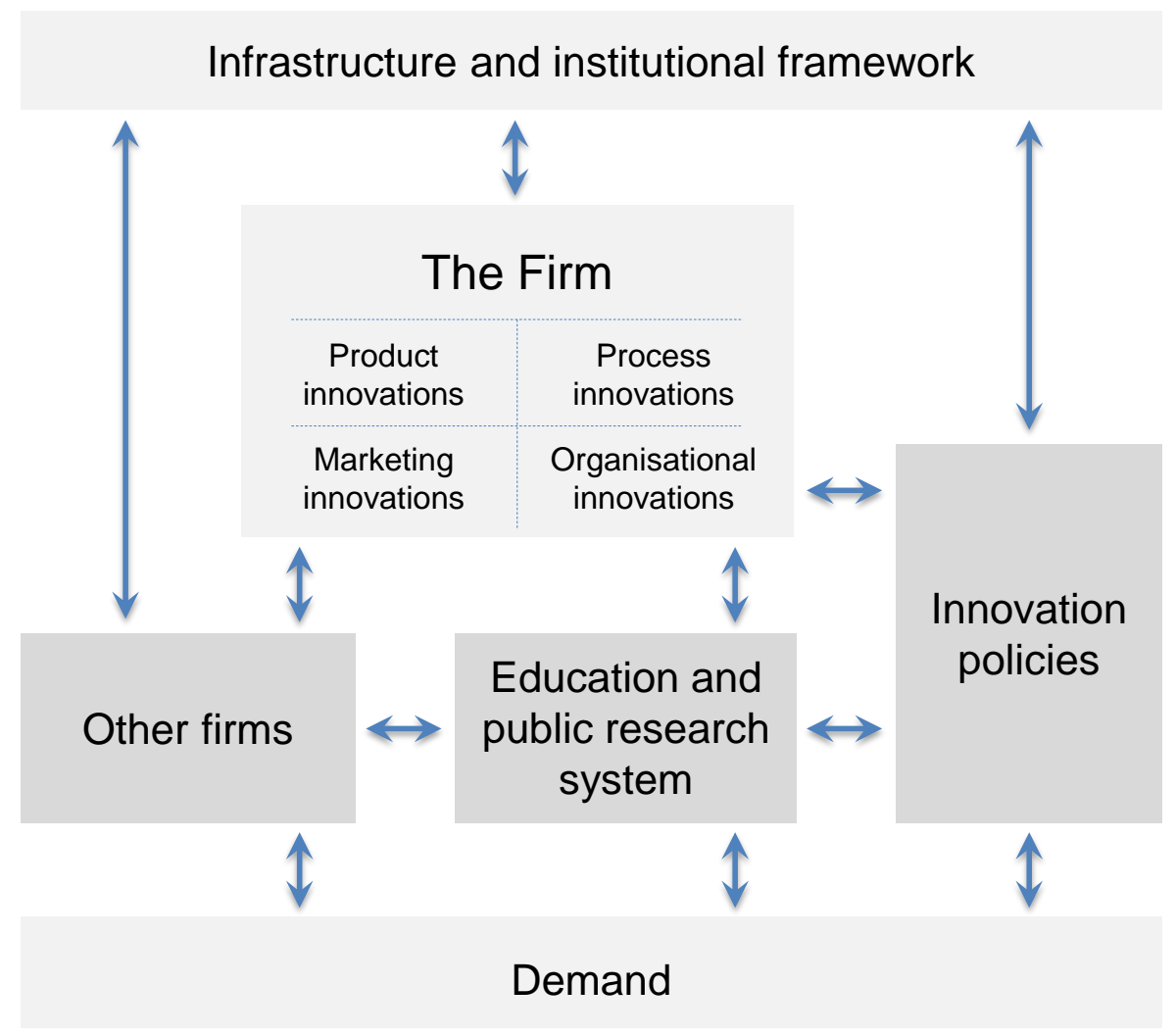

Figure 2: The innovation measurement framework (OCDE, EUROSTAT 2005)

The question for Research Universities is their integration into the national and local systems of innovation, and their interaction with different actors within them. One may wonder if they could not take a leadership role in the initiation of specific innovation ecosystems and the cognitive components in the deployment of these systems.

\section{Business ecosystem model}

In the context of globalization the national and local levels are not the only relevant ones. We must also consider innovation systems focused on sectors and / or multinational companies that develop "business ecosystems" James Moore suggested in 1993 that a company should not be viewed as a member of a single industry but as part of a business ecosystem that crosses a variety of industries. "In a business ecosystem, companies coevolve capabilities around a new innovation: they work cooperatively and competitively to support new products, satisfy customer needs, and eventually incorporate the next round of innovations." (Moore 1993, 76)

Moore follows the logic of Schumpeter, expanding it beyond the firm alone; the whole business ecosystem is at the heart of innovation. The business ecosystem is defined as a business coalition around a major player (keystone firm) which manages to impose its standard but still creates value for its partners through simultaneous cooperation and competition processes. This logic can be linked to the concept of creating shared value (Porter and Kramer 2011), the cooperative innovation (Weaver 2008) or the logic of the investment in social capital understand here as the network.

We go here through a loop: the national innovation systems dominated by the public, the business ecosystems dominated by a keystone firm, and finally other versions of the innovation systems in a territory, a sector... We will not develop here all forms of systems but will propose the design of a general model which will allow us to explore cognitive issues related to them and the role of Universities. 


\section{Institutional framework}

\section{Institutional Analysis Design}

Innovation systems considered as areas of "coopetition" combining cooperation and competition connected to an institutional framework (public goals of sustainable development for example) should be considered in terms of the institutional framework vision. For this we will build on the approach of Elinor Ostrom, and its Institutional Analysis Design (IAD) model, which we propose to adapt.

The IAD approach is based on "the identification of a conceptual unit - called action arena that is subsequently the focus of analysis, prediction and explanation of behavior and outcomes within fixed constraints. Action Arenas include an action situation component and an actor component. Action situations refer to the social space where individuals interact, exchange goods and services, engage in appropriation and provisional activities, solve problems, or fight (among the many things that individuals do in actual situations)." (Ostrom, Gardner and Walker 1994, 28). Orstom puts into perspective the Action Arenas connected to national, regional and/or local formal collective choice and self-organizing collective choice contributing to the operational rules in use in the arena.

\section{The development of formal rules}

Addressing innovation, which can be conceived as a rule changing process, we must deepen the characterization of the types of formal rules that are imposed to action arena actors, and that are considered to be "legitimate". We will not use the term of institutions, which are given a very broad significance by Elinor Ostrom: "the prescriptions that humans use to organize all forms of repetitive and structured interactions" (Ostrom 2005, 3). We will prefer the expression of authority proposed by Max Weber's theory that included three types of authority and/or legitimacy: traditional, charismatic and rational-legal (Weber 1958).

We will distinguish six types of authority that implement all different legitimation mechanisms of rules and knowledge (Figure 3a):

1. Tradition embodied in society by cultural practices and traditional knowledge but also administered by traditional authorities, religious and/or cultural institutions....

2. Politics: collective with political processes and individual behavior where charisma and leadership play a role in driving collective choices

3. Constitutional institutions that underpin the political, democratic mechanisms of delegation of power, and evaluation mechanisms of policy.

4. Standardization within International Standardization Organization (ISO) or any other professional organizations that formalize general rules from the experience of actors whose success is sanctioned by the use made (adopted by the market i.e. rules in use).

5. The scientific community and academia, which have their procedures for peer review, and are reluctant to recognize action arena experience (action research) or vernacular and traditional knowledge.

6. Media covering both the mass media, the press as the Internet, whose legitimacy is based on the popularity and size of audience...

Each of these authorities implements different systems of legitimation of rules and knowledge. These authorities are in competition and the rules they seek to impose on the action arena can be contradictory. 

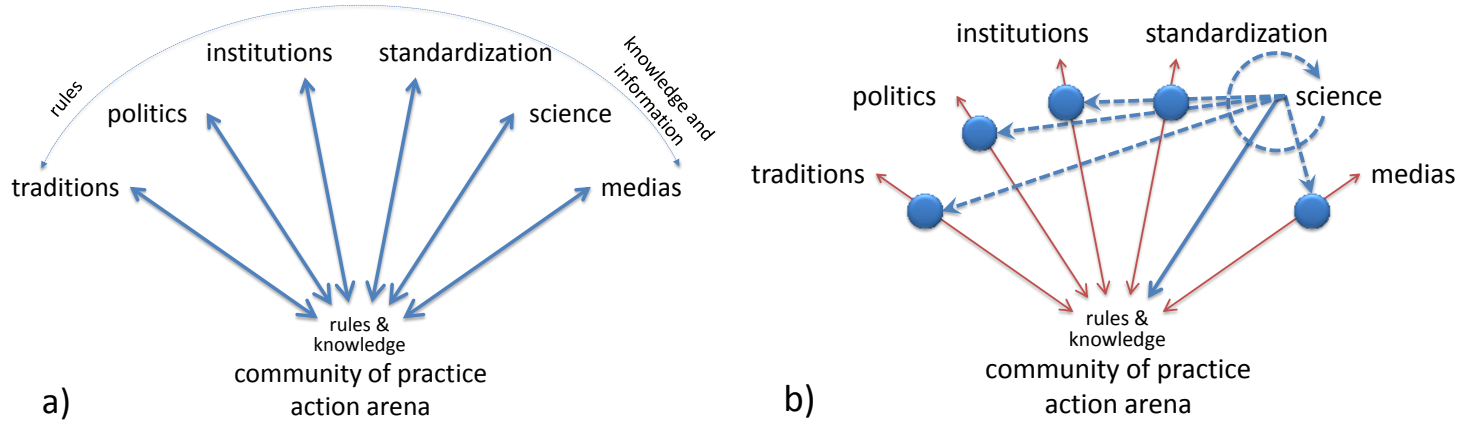

Figure 3 : relation between authorities and action arena and the role of science

The actors of the Action Arena have to practically manage these contradictions and fit rules to theirs intentions and the real-world (social and physical) constraints they perceive, choosing those they find important and relevant in their context.

Similarly actors of the Action Arena mobilize tacit knowledge acquired through experience in close relationships with the real world and other actors. They operate translations between formal and explicit knowledge disseminated by the authorities and their own knowledge acquired through experience

There is a tension between two type modes of learning and innovation: the Science, Technology and Innovation STI-mode based on the production and use of codified scientific and technical knowledge, and the Doing, Using and Interacting DUI-mode an experiencedbased mode of learning. (Jensen, et al. 2007). STI-mode is connected to scientific authority and DUI-mode to Action Arena.

Ikujiro Nonaka proposes a solution for this tension by the creation of environments suitable for the support of knowledge creation, through what he called a "Ba" cycle in four steps: socialization in a face-to-face process of tacit knowledge exchange (in the action arena), externalization through peer-to-peer exchange and translation of explicit knowledge, the combination of group-to-group placed in different situations and internalization a feedback on site closing the loop for new experience and tacit knowledge creation (Nonaka and Konno 1998). Research universities, involved in practical implementation of innovation, should be part of those tacit-explicit knowledge loops.

\section{Figure 4 : relation between authorities and action arena and the role of science}

In summary, an innovation system can be characterized by an interaction of the actors in an Action Arena / innovation ecosystem where they share the use of rules and knowledge partly new. Formal rules and explicit knowledge are mobilized and accommodated to the context of the action. These formal rules and knowledge are issued by 6 authorities who mobilize various institutional mechanisms and legitimacy processes. Implementation of innovation ecosystems requires a harmonization of rules and knowledge from authorities on the basis of new practices experience. Two types of process can contribute:

- A bottom-up approach: Practical experience, rules-in-use and tacit knowledge from action arena / innovation ecosystems must be translated into the formalisms of each institutional frameworks and accommodated with their legitimation mechanisms.

- A horizontal approach through a cooperative negotiation between authorities and the implementation of translation mechanisms.

The Research Universities can get involved at three levels (Figure 3b): 
- in action arena " innovation ecosystems transferring knowledge, engaging in cycles of tacit/explicit knowledge transformation

- in the process of creation of rules and knowledge within institutions and the evaluation of their effective implementation

- in a reflection on their own activities and practice, in both an ethical and epistemological perspective

In this objective we will describe an ongoing project being initiated in the field of renewable energy in West Africa: IPE.

\section{The concept of an Integrated Pole of Excellence.}

An initiative has been taken by the Francophone Institute for Sustainable Development (former IEPF Institute of energy and environment of Francophonie) for capacity building of developing countries through a knowledge platform called Integrated Pole of Excellence (IPE).

It aims to produce and disseminate knowledge on a project basis. These IPE could be nodes in a network of production and dissemination of knowledge. The first prototype is ready to start on energy in West Africa (Gbossou, Brodhag and Bonfils 2010; Brodhag and Gbossou 2011; Brodhag 2011; Benessahraoui 2012)

An initial study has identified six capacities necessary to conduct energy policies: (1) negotiating skills on the international stage, (2) development and implementation of energy strategies and policies, (3) management of the relationship with economic sectors, (4) development of energy projects likely to receive international funding, (5) technology management, (6) evaluation of the sustainability of policies and projects.

Ten activities have been designed to facilitate implementation of an actual regional innovation ecosystem:

1. Research and Development: to produce explicit knowledge contextualized around projects

2. Membership and leadership of scientific networks: integration into networks where knowledge is not contextualized

3. "Vocational" initial education and graduate training: Transmission of explicit knowledge to inexperienced audiences and with low initial knowledge, including internships and professional immersion

4. Professional and in-service training courses : Transmission of explicit knowledge to audiences who already have experience, that is to say, that have tacit and explicit knowledge

5. Participation in projects: Accumulation of practical and tacit knowledge and explicit knowledge generation at ground level (Action Arena / innovation ecosystem)

6. Observation and evaluation of projects and energy policies: Generation of explicit knowledge for authorities which develop formal rules in order to adapt or change them

7. Survey and competitive intelligence activities: Identification of explicit knowledge, and weak signals from tacit knowledge

8. Dissemination of knowledge: explicit knowledge translated for different targets and diffusion

9. Professional Networking: dissemination of tacit knowledge and assessment of explicit knowledge gaps in the field

10. Expertise and advice to decision makers: Formalization of explicit knowledge for the authorities. 
The implementation of all these activities in the same organization (or complementary organizations closely coordinated ${ }^{1}$ ) related to projects in Action Arena / innovation ecosystems. This framework can be considered as the cognitive component of a regional innovation ecosystem.

The issue of capacity building of developing countries is a general question, but the capacity is rarely described. The principles of the Paris Declaration on Aid Effectiveness recommend that aid falls within the priorities of the country. But, in fact, a lack of capacity goes hand in hand with the inability to identify this gap. If there is no skill in a country on an issue either in the administration or among national experts, no one can make the diagnosis of this lack in the country. There is a vicious circle. (Brodhag and Gbossou 2011, 16). The IPE aims to produce new questions itself, according the process of platforms envisaged by Hatchuel et al.: "platforms for platform design will emerge in situation where 1- each actor lacks some capabilities and is unable to produce them alone; 2- none of the actors has a clear view of the value landscape, meaning that the value landscape has to be designed. 3- the design process itself creates capabilities and explores the value; it also reveals missing competencies and unknown areas in the value landscape." (Hatchuel, Le Masson and Weil 2010).

The IPE must be conceived as a process of self-construction. The identification of capabilities will be produced from relationships between actors who use the platform

\section{The contribution of Research Universities}

Research Universities have two interlinked activities (1) research producing and diffusing knowledge and rules, and (2) training of students. From our perspective the knowledge produced cannot be limited only to one aspect of the action arena (a symptom of disciplinary boundaries) but should bring scientific clarification to all actors involved. And training cannot be limited only to the transmission of formal knowledge from the scientific process. Students who will be actors in Action Arenas / innovation ecosystems have to develop different skills.

\section{Research}

In the context of the model we have outlined, we can identify different roles for research:

- The first role is of course to provide new knowledge and new rules to the Action Arena / innovation ecosystems, which is consistent with the logic of technology push

- Identify implemented rules and knowledge in use in the Action Arena,

- Contribute to translate grassroots experiences and tacit knowledge in Action Arena / innovation ecosystems into formal knowledge and rules that can be transmitted to the authorities, i.e. be integrated into Ba processes

- Transfer knowledge in forms understandable by different authorities: expertise and advice to policy makers, outreach to media, participation in standardization activities, dialogues with possessors of traditional knowledge ...

- Explore questions at the interfaces between authorities, conflicts (competition processes) and translation mechanisms (cooperation processes) in terms of knowledge

- Develop epistemological activities in the understanding of the global processes, define modes of action (action research) and rethink the role of research in respect of society expectations and ethical issues.

This design of research involved in the Action Arena, innovation ecosystems and social processes of authorities breaks with the Newtonian model of science and is similar to Mode 2 knowledge production proposed by Gibbon and Al. which makes a distinction between:

\footnotetext{
${ }^{1}$ In this project : 2IE Ouagadougou (Burkina Faso), IFHER Abidjan (Côte d'Ivoire), ENDA Dakar (Sénégal)
} 
"Mode 1 : The complex of ideas, methods, values and norms that has grown up to control the diffusion of the Newtonian model of science to more and more fields of enquiry and ensure its compliance with what is considered sound scientific practice.

Mode 2 : Knowledge production carried out in the context of application and marked by its: transdisciplinary; heterogeneity; organizational heterarchy and transcience; social accountability and reflexivity; and quality control which emphasizes context - and use dependence. Results from the parallel expansion of knowledge producers and users in society." (Gibbons et al. 1994, 167)

\section{Education and training}

Whereas the creation of new jobs will concentrate on innovative sectors in expansion, the training, including that provided in the research universities, must prepare students to become actors and leaders in innovation ecosystems. In this perspective, students must not only acquire the necessary expertise to carry out the task and responsibility which will be given in the framework of the specialization of economic activities... but they must develop their ability to manage the task we described for Innovation ecosystems: tacit and explicit translation activities, to adapt formal rules in practical rules-in-use, and to manage relationships with others actors which carry other rationalities. They will also acquire the competence attached to tacit knowledge: practice in doing, meaning through experience, belonging to the community, and identity through personal becoming (Wenger 1999).

According to their level of responsibility they help produce informal rules and formalize them (Ba) to negotiate relations with the authorities. The roles of managers, described by Mintzberg, which encourage and drive people of their units: "motivate them, inspire them, coach them, nurture them, push them, mentor them, and so on" (Mintzberg 1994, 19) is enlarged to multi-stakeholders relationship in innovation ecosystems.

Secondo et all. develop an Open Business Innovation Leadership concept that contains three fundamental aspects that can be used to describe the strategic priorities of organizations today: "the centrality of developing social capital and enhancing the network of learning relationships; the importance of creating innovation-driven value for all stakeholders; and the founding role of human capital as a cause of organizational development." (Secundo, Margherita and Elia 2009, 97).

This need for a level of vision for managers has been identified by Henri Fayol (Fayol 1916). He suggested that a manager should possess 'culture générale', i.e. knowing things not directly related to his job, things that go beyond the studies of 'administration'. This word 'culture générale' has been translated into English in the Urwick edition by the much narrower expression of 'general education' (Fayol 1949). Fayol also stated that top managers should have technical knowledge and not only 'administrative' knowledge, he should have "the widest possible competence in the specialized activity characterizing the concern" (Fayol 1949, 73). Some scholars such as Mintzberg or Rosanas share this vision and contradict the common belief that specialization in a certain field is the correct path when studying business administration and management (Mintzberg 2004; Rosanas 2006).

This general culture can be acquired "partly at school partly from everyday life" (Fayol 1949, 76). Internships courses allow students to gain experience, their integration into the pedagogical project can lead them to practice the translation of tacit / explicit knowledge. This raises also general questions such as: knowledge flows (translation) in a society, elite's circulation (career with transitions between regimes) and training throughout life, all issues concerning universities.

\section{Universities and sustainable development}

A reflection was conducted in different countries to organize an integrated contribution of universities to sustainable development by establishing frameworks that ensures consistency 
between the management practices of the campus and student life, as well as research and teaching. These frameworks that refer to various scopes lead to the development of various tools and labels.

LiFE (Learning in Future Environments) developed and delivered by the Environmental Association for Universities and Colleges, UK (http://www.thelifeindex.org.uk/)

AISHE (Auditing Instrument for Sustainability in Higher Education), developed and delivered by AASHE (Association for the Advancement of Sustainability in Higher Education), US (http://www.aashe.org/)

QUESTE SI developed for engineering by ENQHEEI (European Network for Quality of Higher Engineering Education for Industry), EU (http://queste.eu/)

Based on legal requirements all French higher education establishments have to set up a Sustainable Development approach based on a framework consistent with French National Sustainable Development Strategy. This framework has been developed jointly by the Conférence des Grandes Ecoles, the Conférence des Présidents d'Universités and their stakeholders. It addresses five core subjects: (1) strategy and governance, (2) teaching and training, (3) research, (4) environmental management and (5) social policy and community involvement. This framework aims at performance and good practices diffusion and not only mature management system. It is accompanied by a self-assessment tool (http://www.evaddes.com/) and a label is accreditation is planned.

This university framework for university guarantee consistency between what is taught and what is practically experienced by students in the campus and the curriculum. The political and social involvement in the community, for example, prepares students to be responsible actors in society able to manage the complexity of relationships within innovation ecosystems.

\section{Bibliography}

Akrich, M., Michel Callon, and Bruno Latour. 1988. A quoi tient le succès des innovations ? 1 : L'art de l'intéressement. Annales des Mines, Gérer et comprendre., 4-17.

Amara, Nabil, Rejean Landry, and Norrin Halilem. 2012. On the measurement of novelty of innovations. Journal of International Business and Economics, 1 May.

Ashford, Nicholas A., and Ralph P. Hall. 2011. The importance of regulation-induced innovation for sustainable development. Sustainability, 270-292.

Asselineau, Alexandre, and Pierre Piré-Lechalard. 2009. Le développement durable : une voie de rupture stratégique ? Management \& Avenir, ed. Cahier : L'organisation revisitée au travers du développement durable : une approche multidisciplinaire: 280-299.

Benessahraoui, Habib. 2012. Vers des pôles intégrés francophones pour le développement durable. Liaison, Energie-Francophonie, juin.

Brodhag, Christian. 2011. Connaissances, réseaux et développement durable. Édité par Institut de l'énergie et de l'environnement de la Francophonie (IEPF). Liaison Energie Francophone, $\mathrm{n}^{\circ} 87\left(1^{\mathrm{er}}\right.$ trimestre $): 64-72$.

Brodhag, Christian, and Christophe Gbossou. 2011. Pôle Intégré d'excellence pour l'énergie : un processus innovant. Liaison Énergie-Francophonie (Institut de l'énergie et de l'environnement de la Francophonie (IEPF)), $\mathrm{n}^{\circ} 87$ (1 ${ }^{\mathrm{er}}$ trimestre) : 15-27.

Brodhag, Christian, Sophie Peillon, Nadine Dubruc, and Florent Breuil. 2011. Responsabilité sociétale et développement durable : un enjeu pour les PME. In PME 2011 - Rapport sur l'évolution des PME, de OSEO, 179-197. Documentation française.

Callon, Michel. 1986. Some elements of a sociology of translation: Domestication of the scallops and the fisherman in st. Brieuc bay. In Advances in social theory and methodology: 
Toward an integration of micro and macro-sociologies, édité par K. Knorr-Cetina and A. V. Cicourel, 196-233. Boston: Routledge \& Kegan Paul.

Chandy, Rajesh, and Jaideep Prabhu. 2011. Innovation Typologies. In Wiley International Encyclopedia of Marketing, édité par Barry Bayus. John Wiley and Sons.

Chesbrough, Henry William. 2003. Open Innovation: The new imperative for creating and profiting from technology. Boston MA: Harvard Business Press.

Di Stefanoa, Giada, Alfonso Gambardella, and Gianmario Verona. 2012. Technology push and demand pull perspectives in innovation studies: Current findings and future research directions. Research Policy.

Dreborg, Karl H. 1996. Essence of backcasting. Futures, November 813-828.

Edquist, Charles. 2011. Systems of Innovation. Perspectives and challenges. Chap. 7 In The Oxford Handbook of Innovation, édité par Jan Fagerberg, David C. Mowery and Richard R. Nelson, 181-208. Oxford: Oxford University Press.

Fayol, Henri. 1916. Administration industrielle et générale. Paris: Dunod.

Fayol, Henri. 1949. General and industrial management. 1971. Edited by L. Urwick. Traduct Constance Storrs. Pitman Publishing, 1949.

Freeman, Christopher. 1987. Technology, policy, and economic performance: Lessons from Japan., 155. London and New York: Pinter Pub Ltd.

Gbossou, Christophe, Christian Brodhag, and Sibi Bonfils. 2010. Étude pour la mise en place d'un Pôle Intégré Excellence en Énergie. IEPF, mars.

Gibbons, Michael, Camille Limoges, Helga Nowotny, Simon Schwartzman, Peter Scott, and Martin Trow. 1994. The new production of knowledge: The Dynamics of science and research in contemporary societies, -. Stockholm: SAGE.

Hansen, Erik G., Friedrich Grosse-Dunker, and Ralf Reichwald. 2009. Sustainability innovation cube - a framework to evaluate sustainability-oriented innovations. International Journal of Innovation Management, Dec.: 683-713.

Hatchuel, Armand, Pascal Le Masson, and Benoît Weil. 2010. Platforms for the design of platforms: collaborating in the unknown. In Platforms, Market and Innovation, 273-305. Edward Elgar.

ISO 26000:2010(E). ISO 26000, Guidance on social responsibility. First edition. Geneva: ISO.

Jensen, Morten Berg, Björn Johnson, Edward Lorenz, et Bengt Åke Lundvall. 2007. Forms of knowledge and modes of innovation. Research Policy: 680-693.

Landry, Réjean, Nabil Amara, and Moktar Lamari. 2000. Does Social Capital Determine Innovation? To What Extent? 4th International Conference on Technology Policy and Innovation, August 28-31, 2000. Curitiba, Brazil.

Lundvall, Bengt-Åke. 1985 Product Innovation and User-Producer Interaction. Industrial Development Research Series $n^{\circ} 31$, Aalborg: Aalborg University Press, 39.

Mercier-Laurent, Eunika. 2011. Les écosystèmes de l'innovation. Paris: Hermes Lavoisier, Coll. Business, économie et société.

Mintzberg, Henry. 2004. Managers not MBAs: a hard look at the soft practice of managing and management development. San Francisco: Berrett-Koehler Publishers.

Mintzberg, Henry. 1994. Rounding out the manager's job. Sloan Management Review, Fall, 11-26.

Moore, Geoffrey A. 1991. Crossing the Chasm: Marketing and Selling High-Tech Products to Mainstream Customers. revised July 1999. New York: Harperbusiness.

Moore, James F. 1993. Predators and prey: a new ecology of competition. Harvard Business Review, May-June: 75-86.

Moore, James F. 2005. Business Ecosystems and the View From the Firm. Antitrust Bull.,3175. 
Mowery, David C., and Bhaven N. Sampat. 2011. Universities in national innovation systems. Chap. 8 In The Oxford Handbook of Innovation, édité par Jan Fagerberg, David C. Mowery and Richard R. Nelson, 209-239. Oxford: Oxford University Press.

Nonaka, Ikujiro, et Noboru Konno. 1998. The concept of Ba : Building a Foundation for Knowledge-Creation. California Management Review, 40 (3): 40-54.

Norman, Donald A. 1998. The Invisible Computer: Why Good Products Can Fail, the Personal Computer Is So Complex, and Information Appliances Are the Solution. Boston: MIT Press.

OCDE, EUROSTAT. 2005. Manuel of Oslo. The measurement of scientific and technological activities proposed guidelines for collecting and interpreting technological innovation data. 3nd ed. Paris.

OECD. 2007. Reviews of Innovation Policy: Chile. Paris: OECD Publishing.

OECD, EUROSTAT. 2005. Oslo manual. The measurement of scientific and technological activities proposed guidelines for collecting and interpreting technological innovation data. 3nd ed. Paris.

Ostrom, Elinor. 2005. Understanding institutional diversity. Princeton, NJ: Princeton University Press.

Ostrom, Elinor, Roy Gardner, and Jimmy Walker. 1994. Rules, games, and common-pool resources. University of Michigan Press.

Porter, Michael E., and Mark R. Kramer. 2011. The big idea : creating shared value. Harvard Business Review, January February 62-77.

Porter, Michael. 1991. America's Green Strategy. Scientific American, April, 168.

Porter, Michael, and Claas van der Linde. 1995. Towards a new conception of environmentcompetitiveness relationship. Journal of Economic Perspectives, Fall: 97-118.

Rogers, Everett M. 1962. Diffusion of innovations. Free Press of Glencoe.

Rosanas, Josep M. 2006. Controversial management theories : implications for teaching and research. Occasional Paper, Barcelona: IESE Business School University of Navarra, 8.

Sagasti, Francisco R. 1979. Towards endogenous science and technology for another development. Towards Another Development in Science and Technology, Development dialogue. Uppsala, Sweden: Dag Hammarskjöld Foundation. 13-23.

Schumpeter, Joseph. 1934. The Theory of Economic Development. Cambridge, Massachusetts: Harvard University Press.

Schumpeter, Joseph A. 1939. Business Cycles: A Theoretical, Historical and Statistical Analysis of the Capitalist Proces. New York: McGraw Hill.

Secundo, Giustina, Alessandro Margherita, and Gianluca Elia. 2009. Networked learning for human capital development. In Open business innovation leadership: the emergence of the stakeholder university, édité par Aldo Romano, 70-108. Palgrave Macmillan.

Vollenbroek, Frans A. 2002. Sustainable development and the challenge of innovation. Journal of Cleaner Production, 215-223.

Weaver, Robert D. 2008.Collaborative pull innovation: origins and adoption in the new economy. Agribusiness. 388-402.

Weber, Max. 1958. The three types of legitimate rule. Berkeley Publications in Society and Institutions. 1-11.

Wenger, Etienne. 1999. Communities of practice: learning, meaning, and identity. Cambridge: Cambridge University Press. 